\title{
Cross-Border Regulations: Exploring Legal Considerations in the United States of Nonprofit Sport Organizations Engaged in International Charitable Work
}

\author{
Per G. Svensson and Anita M. Moorman ${ }^{*}$
}

\begin{abstract}
The number of organizations involved in the use of sport as a means for addressing different social issues continues to grow at a rapid pace. This increasingly includes nonprofit charitable sport organizations registered in the United States. The purpose of this paper is to examine legal considerations related to how domestic and foreign nonprofit entities navigate U.S. laws and regulations impacting their international sport for development (SFD) efforts. This includes the following: (a) an analysis of the legal limitations on domestic nonprofits involved in foreign activities, (b) an evaluation of relevant Internal Revenue Service (IRS) regulations and rulings related to cross-border giving from U.S. domestic charities, and (c) implications for foreign and domestic organizations operating or supporting SFD programs abroad. Findings from this analysis enhance our understanding of legal aspects in the SFD space. Furthermore, the information presented is also intended to serve as a resource guide for SFD practitioners.
\end{abstract}

The number of nonprofit organizations engaged in using sport for promoting positive social change in communities around the world (i.e., sport for development [SFD]) has grown rapidly since the 1990s (Giulianotti, 2012; Giulianotti, Hognestad, \& Spaaij, 2016; Schulenkorf, 2017). SFD encompasses efforts aimed at leveraging sport as a means for promoting peacebuilding, gender equality, social inclusion, career and economic development, and health awareness and disease prevention (Coakley, 2011; Coalter, 2013; Hartmann \& Kwauk, 2011; Schulenkorf, 2012). Many of these programs are initially organized outside of the United States (U.S.) and operate programs within low- and middle-income countries (e.g., Magic Bus in India, SCORE in South Africa, Mathare Youth Sports Association [MYSA] in Kenya). However, there is also an increasing number of foreign charitable organizations implementing SFD programs that are either supported by U.S. domestic charitable organizations (CSOs) or that are

\footnotetext{
${ }^{*}$ Per G Svensson, $\mathrm{PhD}$, is an assistant professor of sport management at Louisiana State University; email: psvensson@lsu.edu. Anita M. Moorman, JD, is a professor in sport administration at the University of Louisville.
}

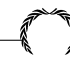


seeking to establish their own nonprofit entities within the U.S. For example, Skateistan, an award-winning organization using skateboarding and educational programming to promote social change in Afghanistan, recently established a nonprofit entity under Internal Revenue Code (IRC) §501(c)(3) in the U.S.

The most recent comprehensive report indicated total private giving to charitable causes in the U.S. exceed $\$ 410$ billion, $\$ 22.9$ billion of which was given in support of international programs/organizations (Charity Navigator, 2019). This situation is of particular importance in light of the recent proliferation of charitable organizations engaged in SFD around the world (Coalter, 2013; Giulianotti, 2012; Schulenkorf, 2017). Since direct donations to foreign charitable organizations are not tax deductible in the U. S., there is a strong interest among these entities in forming domestic charitable organizations that then support and/ or conduct activities in foreign countries. Therefore, the purpose of this paper is to examine legal considerations related to how domestic and foreign nonprofit entities navigate U.S. laws and regulations impacting their international SFD efforts. This contributes to the literature by enhancing our understanding of structural and legal aspects of SFD organizations. Furthermore, this manuscript is intended to also serve as a resource guide for practitioners of nonprofit sport organizations considering cross-border giving from the U.S.

For the purpose of this paper, Section I will provide an overview of how domestic charitable organizations are created and operated within the U.S. to fully explore the legal issues of cross-border giving. In this context, it is imperative to understand how charitable entities are established and operated within the U.S. legal system. In Section II, the legal limitations on domestic CSOs involved in foreign activities are analyzed. The current activities of several notable CSOs under these legal standards and limitations are then evaluated in Section III to determine how and whether they are successfully navigating this complex area of the law. Section IV concludes with a discussion of the implications of these regulations for foreign SFD nonprofits seeking to establish a U.S. charity as well as domestic charitable organizations considering support of foreign SFD programs and organizations.

\section{Overview of Domestic Charitable Organizations in the United States}

According to Berman (2011), the underlying foundation of what constitutes charitable organizations in the U.S. originates from the British Law of Trusts, which suggested charitable organizations include those focused on relief of poverty, advancement of religion, advancement of education, and other purposes considered beneficial to the community (Commissioners for Special Purposes of Income Tax v. Pemsel, 1891). Charitable organizations recognized and operating in the U.S. are subject to both state and federal oversight. The Internal Revenue Service (IRS) evaluates and grants tax-exempt status to eligible organizations, and nonprofit status is determined under the applicable state corporate laws. Essentially, charitable organizations benefit from their nonprofit and tax-exempt status in two significant ways. First, tax-exempt nonprofit organizations are not required to pay U.S. federal taxes on the income they generate through their activities or through donations. Second, donations received by a charitable 
nonprofit organization are tax deductible to the person or entity making the donation, making them attractive for individuals and corporations as a way of lessening their own tax burden while also supporting the charitable work of the organization (IRS, 2017a; Williams \& Seifried, 2013a, 2013b). A charitable nonprofit organization is a specific type of nonprofit organization recognized under the IRC, Section 501(c)(3).

The U.S. District Court for the District of Columbia and the U.S. Supreme Court have both recognized the substantial benefit of tax deductibility not only for the individual donor, but also the recipient nonprofit organization as it is considered a matching grant from the government (Green v. Kennedy, 1970; McGlotten v. Connally, 1972). The tax-exempt status is critically important for most nonprofit organizations to be able to operate and may provide a distinct competitive advantage as well (Williams, 2016; Williams \& Seifried, 2013a, 2013b). Qualifying for tax deductibility for individual contributions in the U.S. is in the best interest of charitable organizations involved in international SFD efforts. Indeed, to operate most effectively, a charitable organization needs to be both organized under state law as a nonprofit entity and obtain tax-exempt status under federal tax law (Williams \& Seifried, 2013a, 2013b).

\section{Determining Tax Exempt Status}

For purposes of determining tax exempt status, Treasury Regulation $\S 1.501(c)(3)-$ 1 defines charitable organizations as "organizations organized and operated for religious, charitable, scientific, testing for public safety, literary, or educational purposes, or for the prevention of cruelty to children or animals" (para. 1). The IRC definition is broader than the original British Law of Trusts definition and includes a variety of activities that promote social welfare as well as activities that lessen the burden of government. In addition to having a qualifying exempt purpose, the CSO must engage primarily in activities for the exempt purpose and no more than an insubstantial part of its organizational activities are for non-exempt purposes. (26 C.F.R. § 501(c)(3)-1(a)(2)(b)). These requirements are known as the "Organizational Test" and the "Operational Test." Under the Organizational Test:

an organization is organized exclusively for one or more exempt purposes only if its articles of organization ...:(a) Limit the purposes of such organization to one or more exempt purposes; and (b) Do not expressly empower the organization to engage, otherwise than as an insubstantial part of its activities, in activities which in themselves are not in furtherance of one or more exempt purposes. (26 C.F.R. § 501(c) (3)-1(a)(2), para. 2)

It is generally sufficient if the articles of organization state that it is formed for charitable purposes to meet the Organizational Test so long as the articles do not empower the organization to carry on activities that are not in furtherance of the stated exempt purpose(s). For example, a charitable organization whose articles also authorized the organization to operate a social club or business would not meet the Organizational Test regardless of the fact that the articles also included charitable activities among its purposes. The articles of organization can 
include trust instruments, articles of association, or any other written instrument by which the organization has been created. (26 C.F.R. $§ 501(c)(3)-1(a)(2)(b)(2))$.

Under the Operational Test, an organization:

will be regarded as operated exclusively for one or more exempt purposes only if it engages primarily in activities which accomplish one or more of such exempt purposes specified in section 501(c)(3). An organization will not be so regarded if more than an insubstantial part of its activities is not in furtherance of an exempt purpose. (26 C.F.R. $\S 501(\mathrm{c})(3)-1(\mathrm{c})$, para. 19)

In order to pass the Operational Test for charitable tax-exemption in the U.S., an organization needs to prove it primarily engages in activities furthering its claimed charitable purpose(s) and no single substantial activity may be for non-exempt purposes (Airlie Foundation v. I.R.S., 2003; Better Business Bureau of Washington, D.C., Inc. v. United States, 1945). Any organization lacking strong supportive material to justify its claims regarding exemption is ruled in the favor of the IRS (New Dynamics Foundation v. United States, 2006).

In determining whether an organization may qualify as a charitable organization, courts in the U.S. have held that organizations must meet both the Organizational and Operational Tests. Specifically, the courts examine whether (1) they engage primarily in activities for the exempt purpose(s) and (2) that no more than an 'insubstantial' part of its organizational activities are for non-exempt purposes (Airlie Foundation v. I.R.S., 2003). An organization meeting both prongs may receive charitable tax-exempt status under IRC §501(c)(3), the most common public charity designation in the U.S.

Courts have traditionally relied on the commerciality doctrine in their assessments of the operational test by considering the extent of commercial (i.e., non-exempt) activities of an organization (e.g., BSW Group, Inc. v. Commissioner, 1978; Easter House v. United States, 1987). The Supreme Court has held a single substantial non-exempt purpose will terminate any argument for exemption status regardless of the number or importance of an organization's truly exempt purposes (Better Business Bureau of Washington, D.C., Inc. v. United States, 1945).

If an entity is denied charitable status by the IRS, the organization has the burden of proof to demonstrate how the IRS determination was incorrect and that the organization has met the requirements under the IRC statute for which it claims tax-exemption status (Church of the Visible Intelligence that Governs the Universe v. United States, 1983; Harding Hospital Inc. v. United States, 1974). The petitioning organization must provide unambiguous evidence of its qualification for exemption status (United States v. Wells Fargo Bank, 1900).

In New Dynamics Foundation v. United States (2006), the plaintiff challenged the grounds of the denial of its tax exemption. The facts of the case indicated its founder had operated the organization for personal benefits rather than in furtherance of a charitable mission. The foundation argued the founder was no longer with the organization at the time of the hearing. However, the court did not find substantial evidence of change (e.g., written documentation of organizational procedures and processes) other than the reported replacement of one staff member. This case highlighted the burden of proof of the organization 
in challenging exemption qualification. The court suggested any cases involving concerns over limited administrative records are ruled against the petitioner.

\section{Types of Tax Exempt Organizations: Public Entities and Private Foundations}

The IRC recognizes 28 categories of tax-exempt organizations (Fritz, 2016). The most common type of nonprofit organization is the 501(c)(3), tax-exempt charitable organization. Tax-exempt organizations are generally classified as "public benefit organizations" and "mutual benefit organizations," the vast majority of which fall into the classification of "public benefit or charitable organizations" (GuideStar, 2017). Public benefit organizations work for the greater good of the public such as a YMCA of the USA or The "V" Foundation, while mutual benefit organizations work for the betterment of a select group of members such as the National Collegiate Athletic Association (NCAA). Public benefit organizations tend to also be separated into two sub-categories, public charities and private foundations. For example, there are more than 1.5 million tax-exempt organizations in the U.S., and of those more than 1 million of them are public charities and around 105,000 are private foundations (National Center for Charitable Statistics, 2013). Both public charities and private foundations may enjoy the dual tax benefit applicable to both revenue and donations.

The primary difference between public charities and private foundations tend to relate to their activities, reporting requirements, and control/oversight. For example, public charities would likely operate actual charitable activities such as direct operations of programs and services both domestically and abroad. Public charities enjoy higher donor levels, simplified tax filing requirements based on the amount of revenue, and they can receive donations from private foundations. Public charities are governed by a board that cannot have more than $50 \%$ of its membership related by blood, marriage, or business co-ownership and a minimum percentage of its revenue must come from small donors. Classic examples of public charities include the United Way, Salvation Army, Boys \& Girls Clubs of America, YMCAs, the Muhammad Ali Center, and hundreds of professional athletes' charitable organizations.

On the other hand, private foundations support the work of public charities through fundraising efforts and primarily manage a fund that may award grants to support the work of other public charities. For example, a private foundation is often created by an initial endowment or gift and then the interest earnings on the principal endowment are used to award grants to serve the mission of the foundation. Private foundations must file lengthy and oftentimes complicated tax reports regardless of the amount of revenue and while they may award grants to foreign charities those distributions may or may not count as a qualifying distribution for the foundation (Peebles, 2017). Donations to private foundations are only tax deductible for the donor of between $20-30 \%$ of adjusted gross income, compared to the $30-50 \%$ deductibility available for donations to public charities (Walsh, 2012). Interestingly, the name "foundation" may be confusing since many prominent sport foundations such as The Tiger Woods Foundation or the Troy Aikman Foundation for Children are actually public charities, but the term foundation is commonly used by professional athletes to communicate their philanthropic mission (Walsh, 
2012). If a nonprofit charitable organization is unable to qualify as a public charity, it will by default be classified as a private foundation.

Maintaining public charity status can be challenging to demonstrate that the requisite percentage of your funds are coming from the general public. Rather than to be reclassified as a private foundation, some public charities may also choose to dissolve and create a donor-advised fund within a larger, more established public charity. In this situation, the fund is separately identified and legally controlled by the public charity, but the donor retains advisory privileges over distributions and investment of assets. For example, Troy Aikman announced in 2016 that he would be dissolving his Troy Aikman Foundation for Children and transfer its $\$ 1$ million in assets to the United Way of Metropolitan Dallas (Hunter, 2016).

The IRS issues letter rulings to provide timely response to taxpayers who are trying to determine the tax consequences of specific acts or transactions. These rulings provide general guidance as to how the tax laws would likely be interpreted (CCH Tax Law Editors, 2016). Prior tax rulings have not directly involved SFD organizations; however, the IRS private letter rulings and revenue rulings are useful to SFD organizations in understanding how the legal requirements may impact them. SFD organizations, as other nonprofit charitable organizations, are established to address specific social inequities and contribute to the public good. Therefore, these IRS rulings are insightful and useful for the purpose of our analysis given the social change-focused nature of SFD where sport is combined with various non-sport activities to achieve development and peace-building goals (Giulianotti et al., 2016; Kidd, 2008). Thus, to illustrate how to navigate these legal requirements, we will highlight two hypothetical SFD organizations: Football Hope and Sport 4 Society. In our case, Charlie Smith previously founded Football Hope, an award-winning SFD organization registered in Israel that uses football (i.e., soccer) as a means for delivering educational and conflict-resolution programs in divided communities in several areas in the Middle East. She has recently retired from her leadership role with Football Hope and now wants to establish a new SFD organization (Sport 4 Society) as a registered public charity in the U.S. to further support the SFD efforts abroad.

\section{Limits on Domestic Charitable Organizations' Activities}

Historically, the U.S. has remained territorial in determination of tax deductions for individual contributions to charitable organizations (Johnson, 2013; Paine, 2004; Pozen, 2006). As a result, the U.S. does not allow for tax deductibility for contributions directly to foreign organizations. Thus, a U.S. citizen who donates funds to support the activities of a foreign charitable organization (e.g., a direct donation to Football Hope) may not deduct these charitable contributions as an itemized deduction under U.S. tax laws. While public entities may conduct exempt activities in foreign countries and benefit from the tax deductibility of donations made to support its international programs, a foreign charitable organization may struggle to obtain donations from the U.S. In addition to restricting the tax deductibility of donations to foreign organizations, the regulations of IRC §501(c) (3) also prohibit lobbying or any other political involvement as a substantial activity by the organization seeking charitable status (I.R.S., 2017a). Although 
lobbying might be considered acceptable behavior in a given foreign culture, the IRS clarified in Revenue Ruling 73-440 (1973) that any such conduct by an organization still bars it from charitable exemption under IRC §501(c)(3). Any SFD organizations engaged in political or lobbying action as a substantial part of their activities may still receive tax-exempt status under IRC §501(c)(4) (i.e., exempt from income taxes). However, such designation does not provide tax deductibility for individual contributions.

Consequently, a foreign charitable organization may seek to form a U.S. domestic charitable organization to support its programs and activities conducted outside of the U.S. In Revenue Ruling 71-460 (1971), the IRS clarified that an organization conducting some or all of its charitable activities abroad is not prohibited from exemption under IRC \$501(c)(3). Thus, Sport 4 Society could receive charitable exemption in the U.S. even if all of its SFD programs are operated abroad such as in the Middle East. According to the IRS, an organization providing training for individuals aimed at developing its capabilities qualifies for charitable exemption in the U.S. (Rev. Rule 65-298, 1965). The clear link between SFD and the development of capabilities (cf. Darnell \& Dao, 2017; Svensson \& Levine, 2017), further suggest these entities qualify for charitable exemption under IRC §501(c)(3) in the U.S.

In another example, an organization operating training programs aimed at social and economic development in rural communities within low-income countries was also ruled to qualify for exemption under IRC $\S 501(\mathrm{c})(3)$ (Rev. Rule 68-117, 1968). Similarly, in Revenue Ruling 74-16 (1974), an organization formed to educate individuals in low-income countries about credit problems for increasing their quality of life was deemed to qualify for exemption under IRC $\S 501(\mathrm{c})(3)$.

\section{Adequate Discretion and Control}

In a 2009 letter ruling, the IRS ruled an organization did not qualify for taxexemption status in the U.S. under IRC §501(c)(3) and that individual donations were therefore not tax deductible under IRC $\$ 170$ for failure by the organization to maintain adequate discretion and control of funds (PLR 200931059, 2009). The organization claimed to be formed in order to provide stipends to poor students for attending programs of a foreign entity for religious education (PLR 200931059 , p. 2). The applicant organization claimed it was independently formed and that individual contributions in the U.S. were not earmarked for the foreign organization. In fact, the applicant organization claimed the foreign entity received no direct funds since only students attending educational programs of the foreign entity were the beneficiaries. Recipients reportedly had to be approved by the organization, yet it did not have a formal selection committee.

In addition to numerous inadequacies in the organization's governing documents and organizational structure, the IRS also found the organization failed to provide detailed and transparent criteria for determination of how funds were distributed. Simply providing the total dollar amount per year and per recipient was deemed insufficient (PLR 200931059, pp. 4-6). Moreover, the applicant organization tried to justify its definition of 'needy' or 'poor' students based on information provided on family income, but did not include any specific details 
on how income figures were evaluated and what specific amount qualified applicants for grants. Furthermore, despite the organization claiming it exercised control over distribution of funds, it turned out that a volunteer living abroad in the foreign country of operation made the final decisions regarding cash distributions (PLR 200931059, p. 4). The IRS found this problematic as none of the board members listed in the initial application lived in the foreign country. The same individual was found to hand out large sums of cash from the organization without keeping detailed records of how and where such funds were distributed. In addition, the applicant organization was not only found to rely on a volunteer responsible for controlling the use of funds, but also relying on a foreign organization for reportedly maintaining records of recipients (PLR 200931059, p. 5).

Additional discrepancies emerged whereby the applicant organization was unable to provide any records of meeting minutes despite having such responsibilities listed for one of the organizational members in its bylaws. The IRS concluded the petition organization did not maintain adequate control and discretion of funds donated in the U.S. as it was unable to provide detailed evidence of how it maintained records of recipients' names, addresses, amounts distributed, purpose for contribution, how individuals were selected to receive contributions, and any relationship(s) between the recipients and organizational members (Rev. Rule 56-304, 1956). The IRS also commonly examines adequate discretion and control over funds in matters related to tax deductibility for contributions to organizations involved in cross-border giving.

\section{Tax Deductibility of Individual Contributions for Cross-Border Giving}

In Revenue Ruling 63-252 (1963), the IRS discusses the tax deductibility of contributions under IRC $\S 170$ (a) using five distinct examples of dealings between domestic charitable organizations and foreign charitable organizations. These examples are further illustrated in Figure 1. This ruling is commonly used as the foundation in subsequent revenue rulings regarding cross-border giving when the domestic organization is assumed to meet the organizational and operational requirements of IRC $\S 170(c)(2)$. In three of the five cases (Examples 1,2 , and 3 ), the charitable organization would not retain its tax deductibility for individual donations. First, a foreign organization forming a domestic charitable organization in the U.S, which is used to conduct fundraising campaigns and transmitting collected funds directly to the same foreign organization, does not qualify for tax deductibility. Second, individuals in the U.S. forming a domestic organization suggesting individual contributions will go directly to a specified foreign entity (i.e., 'earmarking' donations) is also considered non-deductible as the domestic organization is merely acting as a financial conduit for the foreign charity. Third, a domestic organization conducting fundraising campaigns in the U.S. on behalf of foreign entity through a partnership agreement also fails to qualify for tax deductibility on individual contributions.

The IRS also provided two sample cases for which a domestic charitable organization would retain its tax deductibility for individual donations (Figure 1; Rev. Rule 63-252, 1963). The first example included a domestic organization conducting a variety of charitable activities in a foreign country in furtherance 


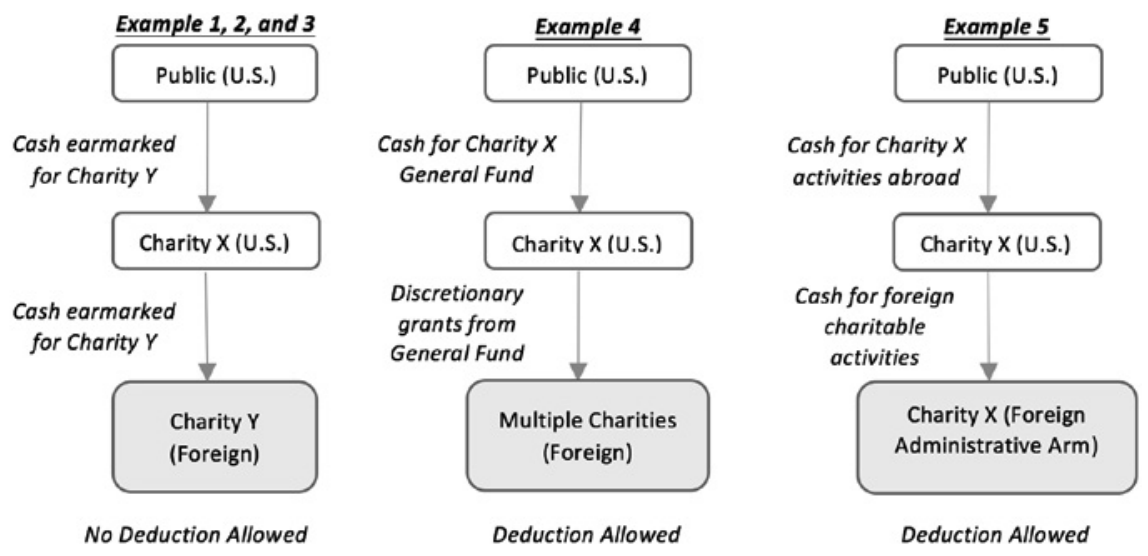

Figure 1. A visual overview of examples provided in IRS Rev. Rul. 63-252

of its exempt purpose(s) following an internal review and approval process. Moreover, the sample domestic charitable organization did not solicit funds for a specific foreign charitable organization. The second example included a domestic organization, which formed a foreign organization in a country of its charitable work for administrative purposes. The domestic organization retains control of every facet of the foreign entity and will transmit solicited funds for its charitable work from the domestic charitable organization toward its administrative entity abroad. Considering the relatively broad nature of these five cases, the basis of Revenue Ruling 63-252 (1963) has been expanded and further clarified by the IRS in subsequent revenue and private letter rulings as well as in IRS determination letters (e.g., Department of the Treasury, 2013; PLR 200931059, 2009; PLR 201016089, 2010; Rev. Rule 66-79, 1966; Rev. Rule 68-489, 1968).

Therefore, Sport 4 Society needs to establish clear decision-making processes and maintain detailed records of how funding recipients were identified, evaluated, and selected. Charlie Smith would not be granted exemption and tax deductibility for donations if Sport 4 Society is intended to serve as a fundraising arm for Football Hope with all funds earmarked for its operation. Instead, her new organization needs to be able to provide supportive documentation that indicates how the U.S. charitable organization exercised control of the distributed funds. These regulations do not preclude Sport 4 Society from supporting Football Hope, as long as the organization meets the evaluation criteria and is one of several foreign SDP agencies to be supported. This would help further support that Sport 4 Society maintains adequate discretion of and control of funds. 


\section{Cross-Border Giving from U.S. Charitable Organizations Involved in SFD}

The creation of entities such as Skateistan under IRC §501(c)(3), which does not conduct any program operations within the U.S., are seemingly to incentivize individuals to make individual donations in support of the foreign program. The U.S. is attractive to international programs since the U.S. has among the highest percentage of population giving money to charitable organizations. As mentioned previously, total private giving to charitable causes in the U.S. in 2012 in support of international programs/organizations exceeded $\$ 22$ billion (Charity Navigator, 2019). Giving to international causes experienced a decline in 2013 and 2014 but rose $17.5 \%$ in 2015 to an estimated $\$ 15.75$ billion. The rebound has been attributed to growth in the number of active international charitable organizations, more strategic fundraising, and increased focus on international issues among foundations (GivingUSA, 2016).

With the exception of bilateral tax treaties (e.g., between the U.S. and Israel, Canada, and Mexico), individual donations to foreign charities are not currently tax deductible under IRC $\$ 170$. Therefore, SFD organizations are increasingly establishing domestic entities within the U.S. to encourage individuals to donate to a registered U.S. charity for tax-deductible benefits. A common misconception regarding charitable contributions in the U.S. is that all donations to nonprofits are tax deductible. Tax-exemption status in the U.S., however, does not guarantee all individual contributions are tax deductible under IRC $\$ 170$ (Rev. Rule 63-252, 1963). Tax deductibility in regards to cross-border giving depends on several legal considerations regarding organizational structures, procedures, and the manner in which organizations conduct such activities.

\section{Qualified Foreign Recipients of Cross-Border Grants}

A charitable organization in the U.S. interested in providing financial grants to a foreign entity needs to provide evidence that the recipient organization fulfills the requirements of charitable organizations under $\$ 501(\mathrm{c})(3)$. An organization conducting some or all of its charitable activities abroad is not necessarily prohibited from exemption under IRC \$501(c)(3) (Rev. Rule 65-298, 1965; Rev. Rule 68-117, 1968; Rev. Rule 71-460, 1971). The applicant organization, however, carries the burden of proof to provide clear evidence that it qualifies for exemption under the IRC (Church of the Visible Intelligence that Governs the Universe v. United States, 1983; Harding Hospital Inc. v. United States, 1974; United States v. Wells Fargo Bank, 1900).

The domestic charity (e.g., Football Hope) might use one of several strategies for supporting that the recipient organization should be considered a charitable entity under the IRC. Legally, a foreign charitable organization interested in receiving monetary funds from a charitable organization in the U.S. can seek an IRS determination letter by applying for recognition of exempt purposes under IRC $\$ 501(c)(3)$. A determination letter is a written reflection of the decision by the Director of the IRS of the application of IRC principles. In the context of a foreign charitable organization, a determination letter provides sufficient evidence that the foreign entity is considered a charitable organization under IRC §501(c)(3) 
and no further justification is needed by the U.S. charity for making cross-border grants. Therefore, a monetary grant from a nonprofit in the U.S. to a foreign organization with an IRS determination letter is desirable for the grantor as it saves them additional administrative work from not having to provide alternative justifications of the eligibility of the recipient entity.

In reality, however, few charitable organizations abroad tend to complete the process of obtaining an IRS determination letter (Jenkins, 2007). The application process for exempt-recognition of foreign organizations by the IRS is a tedious and costly process (Johnson, 2013). This process is not only associated with initial administrative and monetary challenges for the foreign entity, but also ongoing reporting requirements for maintaining the IRS tax-exempt determination. In the event that a prospective foreign recipient does not have a determination letter, the grantor is required to provide alternative justification or the qualification of the recipient organization in the foreign country. These alternative justification requirements include the demonstration of how adequate control and discretion of funds is maintained by public charities and the equivalence determination or the expenditure responsibility procedural process tests for private foundations. These contexts will now be analyzed in more detail to examine legal considerations of cross-border giving.

\section{Financial Support by Public Charities to Foreign Organizations}

If a charitable organization in the U.S. (e.g., Sport 4 Society) choses to pursue the strategy of making cross-border financial grants, the organization must maintain adequate discretion and exercise control over the funds to prove it did not merely act as a financial conduit for a foreign organization (Rev. Rule 66-79, 1966; Rev. Rule 68-489, 1968; Rev. Rule 75-65, 1975). Similar to any challenges of IRS determination of charitable status, the organization carries the burden of proof in establishing that any financial grant provided to a foreign entity was made in efforts to further the exempt purpose of the organization under IRC §501(c)(3) (Rev. Rule 68-489, 1968). Although financial grants by domestic public charities to foreign charitable organizations are permitted as long as the domestic charity maintains adequate discretion and control over the funds, the IRS has not provided clear guidelines for these organizations to follow. Instead, the IRS has hinted at its conceptualization of what constitutes so-called 'adequate' discretion and 'control' of funds through various revenue rulings (see Figure 2).

Grants for specific foreign programs. In a series of revenue rulings, the IRS has considered whether individual contributions to a domestic charitable organization would be considered tax deductible when a domestic organization made occasional donations for specific projects of a foreign charitable organization after approving such project serving in furtherance of its exempt purpose(s). For example, in Revenue Ruling 66-79 (1966), the IRS considered individual donations to be tax deductible since the contributions were considered to be for the use of the domestic charitable organization rather than for the foreign charitable organization receiving the financial grant. An important highlight of this case was the notion that the domestic organization was not considered to function as a fundraising arm for the foreign organization; rather, its founders wished to only support specific projects (e.g., scientific research projects) carried out 


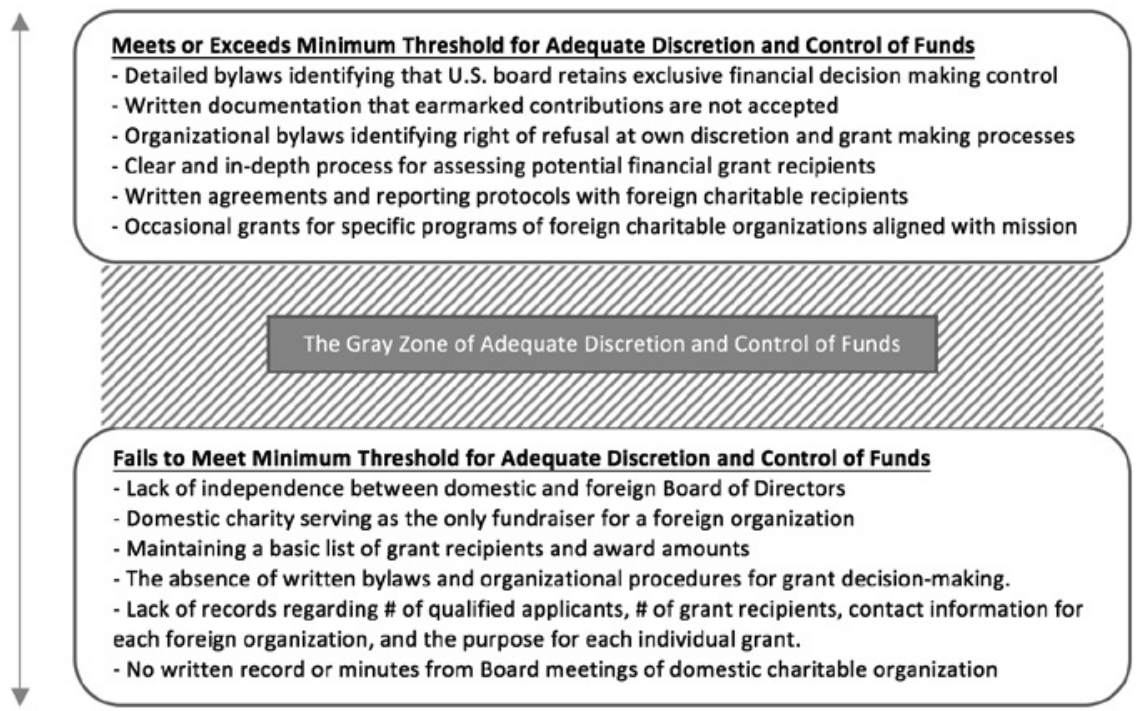

\section{Figure 2. A visual overview of IRS precedent regarding Adequate Discretion and Control of Funds}

by the foreign entity in furtherance of its charitable mission. These procedures were supported by detailed organizational bylaws outlining how the domestic organization reviewed and evaluated international grant applications. Hence, Sport 4 Society could support specific programs operated by Football Hope (e.g., pilot employability program for girls and women) as long as it aligns with the mission of Sport 4 Society.

Additionally, the CSO's bylaws (cf., Rev. Rule 66-79, 1966) specified the following: (a) the U.S. board retained the exclusive power of making decisions regarding financial grants; (b) the U.S. board also had the power to make financial contributions in furtherance of its exempt purpose(s) to organizations operated exclusively under the requirements of IRC $\$ 501(c)(3)$; (c) the U.S. board reviewed requests for financial grants from organizations demonstrating how such funds would be used; (d) the U.S. board also required recipients of grants to provide financial accounting records in support of the use of granted funds; and (e) the U.S. board of directors maintained the exclusive power to refuse and/or withdraw any financial grants (even after initial grants may have been approved).

Lastly, the domestic charitable organization in Revenue Ruling 66-79 (1966) also had written documentation that it refused to accept any individual contributions earmarked for a particular foreign charity or program. The detailed written provisions in the organization's charter were considered substantial and sufficient for supporting that the domestic charitable organization maintained adequate discretion and control of funds. Therefore, it is imperative to consider the use of similar language and detail in the creation of Sport 4 Society and its organizational bylaws. 
Bylaws and organizational procedures similar to those present in Revenue Ruling 66-79 (1966) were also used by a domestic organization under review in Revenue Ruling 75-65 (1975). This particular organization supported wildlife preservation efforts in foreign countries, but the grantor managed all expenditures involved with the cross-border funding program by conducting in-depth assessment of potential recipients, entering into a written agreement with qualified and chosen recipients, and by tracking the use of distributed funds on a continuous basis. The IRS ruled such efforts to constitute adequate discretion and control and therefore qualified individual contributions for tax deductibility.

Organizational structure and procedures. Revenue Ruling 63-252 (1963) was cited in a 2013 IRS determination letter, which denied an organizational request for tax-exempt status under IRC §501(c)(3) (Department of the Treasury, 2013). The IRS determination letter is of particular interest for the purpose of the current discussion as the applicant domestic organization claimed its purpose to be supporting charitable educational activities of a specific foreign organization. The tax-exempt request was denied for several reasons including the fact that the domestic organization served as the sole fundraiser for the foreign charity. In addition, the domestic organization had indicated it only accepted donations earmarked for the foreign charity in its application submitted to the IRS. Furthermore, the board of directors of the domestic organization lacked independence, as several members were located abroad and even included internal stakeholders of the foreign organization. Hence, it is crucial for Charlie Smith to ensure that she recruits a new set of board members for Sport 4 Society, whom are not connected to Football Hope. The IRS also noted a lack of evidence for establishing how the domestic organization maintained adequate discretion and full control of donated funds, as it found no evidence of any established organizational procedures for reviewing funding requests before approving international grants. This decision is further supported by several court decisions.

For example, simply maintaining a list of recipients of grants as well as a list of written reasons for the grant have been deemed insufficient for showing how grants are made in furtherance of exempt purpose(s) (Church in Boston $v$. Commissioner, 1978). Tax courts have also upheld the denial of tax-exempt status under IRC $\$ 501(\mathrm{c})$ for failure by organizations to maintain adequate records of financial transactions and organizational procedures (Western Catholic Church v. Commission, 1979), as well as for failing to provide detailed information on organizational activities for which tax-exemption status is claimed (Peoples Prize v. Commissioner, 2004). These examples raise awareness of the importance for international SFD organizations to maintain detailed records in order to be able to provide clear evidence of its organizational procedures in determining international grants as being in furtherance of their exempt purpose(s). A recent private letter ruling provides additional insight into what the IRS considers sufficient control of funds for cross-border giving in furtherance of exempt purpose(s) (PLR 201016089, 2010).

Importance of detailed organizational documentation. In PLR 201016089 (2010), the IRS ruled the applicant organization did not qualify for tax-exemption status in the U.S. under IRC $\$ 501(\mathrm{c})(3)$ and that individual donations were not tax deductible under IRC $\$ 170$ due to inadequate evidence of the manner in 
which the organization conducted its activities. Revenue Ruling 59-95 (1959), in which the IRS ruled failure by an organization to provide complete records and required documentation can result in denial or revocation of charitable exemption, guided the IRS decision. Revenue Rulings 63-252 (1963), 66-79 (1966), and 68-489 (1968) were also cited by the IRS in its analysis and justification of its ruling. The organization in PLR 201016089 claimed to be formed for the purpose of supporting program activities of a foreign organization and arguably required the foreign recipient to provide ongoing updates of how funds were used to further its charitable mission. The IRS, however, requested more detailed information on the organizational process regarding its cross-border grants.

Specifically, the organization was asked to provide evidence on records regarding: (a) number of organizational grant applications, (b) number of organizations qualified for grant, (c) number of organizations selected to receive grant, (d) name and address of recipient, (e) amount of monetary grant, and (f) purpose of the grant for each recipient. The petition organization did not provide such evidence and admitted only one foreign organization had applied for a grant. The IRS further found the organization did not have a procedure requiring any type of written applications as it suggested grants were determined through oral requests. Unlike the nonprofits in Revenue Rulings 66-79 (1966) and 75-65 (1975), the organization in this particular letter ruling did not have clear bylaws and procedures in place for ensuring the domestic charity retained ultimate control over funds or ensuring they were used in furtherance of its mission. Moreover, one of the board members of the organization was discovered to be the founder of the foreign organization. Although this individual was removed from the board, the court interpreted this as merely removing the individual from the organization on paper as the person continued to be involved in the organizational activities by making decisions on the use of its funds. The IRS suggested the acts of allowing the founder of a foreign entity to exercise control and verify the use of funds for intended purposes did not constitute adequate control and discretion under Revenue Ruling 63-252 (1963). The organization was also unable to provide any records of meeting minutes as requested by the court. This decision points to the importance for SFD organizations such as Sport 4 Society to develop sufficient organizational infrastructure for maintaining detailed records for all SFD funding activities.

Another point of interest in this case was the acknowledgement by the court that the clear connection between the organizational name and the foreign organization receiving funds somewhat discredited the broader purpose described in organization documents. Nonetheless, the final decision was not solely based on the connection between the names of the organizations, rather the manner in which the organization carried out its activities. Thus, the establishment of socalled 'Friends of' organizations - in clear support of a foreign entity - does not prohibit them from making cross-border grants to such entities as long as they are able to provide evidence that the U.S. entity maintained adequate control and discretion of the use of funds solicited in the U.S. rather than merely serve as a financial conduit for the foreign entity (Rev. Rule 63-252, 1963). 


\section{Financial Support by Private Foundations to Foreign Organizations}

Considering the popularity and growing establishment of sport-related private foundations, it is also worth considering tax implications of foundations seeking to support foreign SFD efforts through financial grants. As mentioned in the previous section, a private foundation faces greater scrutiny than a public charity related to its tax filings, disclosures, and reporting requirements (Jenkins, 2007). International grant making requires a foundation to elect either the equivalence determination or the expenditure responsibility procedural process (IRC $\$ 4945(\mathrm{~d}$ ) (4)). The equivalence determination process requires a private foundation to prove the foreign recipient of a financial grant is equivalent to a U.S. public charity under IRC $\S 509$ (a). Therefore, the foreign charitable recipient must be

Organized and operated exclusively for religious, charitable, scientific, testing for public safety, literary, or educational purposes, or to foster national or international amateur sports competition (but only if no part of its activities involve the provision of athletic facilities or equipment), or for the prevention of cruelty to children or animals. (IRC $\$ 501(\mathrm{c})(3)$, para. 31)

A domestic foundation can establish the equivalency determination through the written opinion of its legal counsel or based on a written affidavit from the foreign charity (Rev. Proc. 92-94, 1992). A written affidavit must include a description of the organization's activities, financial information and history, copies of its bylaws, and supportive documents indicating the organization does not engage in substantial lobbying, political intervention, or private inurement (Rev. Proc. 92-94, 1992). Although foreign SFD organizations may be equivalent to a public charity in the U.S., the equivalence determination procedural process is often timely and costly for nonprofit organizations (Jenkins, 2007).

The other option for a private foundation is to elect the expenditure responsibility procedural process (IRC $\S 4945(\mathrm{~d})(4)$ ). These regulations require the foundation to conduct a pre-grant inquiry to assess if the proposed recipient is reasonably likely to use the financial grant for the specified purpose(s), sign a written agreement with the recipient organization, and report the expenditure responsibility grant on its annual financial documents (i.e., Form 990) filed with the IRS. The recipient organization must also submit a written annual progress report on the use of the financial grant to the granting foundation as well as maintain the received funds in a separate bank account (IRC $\$ 4945(d)(4)$ ).

\section{Implications for Foreign and Domestic Organizations Operating or Supporting SFD Programs}

The analysis in this paper highlights the importance for both foreign and domestic charitable organizations to recognize the multitude of restrictions and regulations for domestic charitable entities engaged in cross-border giving. It is imperative for managers of these organizations to understand the necessary 
structures and procedures needed for qualifying for exemption in the U.S. and for retaining tax deductibility for individual donations. Charitable organizations operating in communities around the world are attracted to the U.S. since its citizens are historically among the top individual donors in the world. This has resulted in the establishment of several 'Friends of' organizations within the U.S. for supporting foreign entities. Establishment of such organizations, however, is often based on the misguided premise that all individual contributions to a registered nonprofit are tax deductible. The reality is that a U.S. charitable organization may not merely act as a financial conduit for a foreign charitable organization (Rev. Rule 63-252, 1963).

A domestic public charity may financially support foreign programs and organizations as long as the U.S. entity maintains control and discretion over the use of its funds (Rev. Rule 66-79, 1966; Rev. Rule 68-489, 1968; Rev. Rule 75-65, 1975). Unfortunately, the IRS has yet to provide clear guidelines for what it considers adequate control and discretion over funds used for cross-border giving. Revenue Ruling 63-252 (1963) provided five general case examples of whether individual contributions qualify for tax deductibility. Although the ruling did not provide specific details, it did clarify a domestic organization may not merely serve as a financial conduit of a foreign entity. This ruling has since served as the foundation in IRS rulings and determinations regarding cross-border giving of domestic organizations.

In Revenue Ruling 66-79 (1966) and Revenue Ruling 75-65 (1975), the IRS ruled the respective organizations to exercise discretion and control of funds, in large part due to detailed organizational bylaws outlining how the grantors retained the exclusive right to review and evaluate international grant applications and distributions of funds. These bylaws further noted the organization retained the right to refuse or withdraw grants at its own discretion if not in furtherance of its charitable purpose. In a more recent ruling, the IRS concluded a list of a number of recipients and the average grant amount without any specification on standards and criteria for grant, purpose of grant, contact information of grant recipient, or how the organization selects recipients did not constitute sufficient control over funds (PLR 200931059, 2009). In contrast to the organizations in Revenue Rulings 66-79 (1966) and 75-65 (1975), the organization in the aforementioned did not have detailed records of the grant decision-making process.

Precedent revenue rulings and tax court decisions suggests a public charity accepting and distributing contributions earmarked for a foreign SFD program or organization will not be granted tax deductibility for individual contributions. As a result, existing public charities need to provide evidence in support of the control of funds by the U.S. organization rather than a foreign entity. For example, an existing SFD organization clearly states the purpose of its §501(c) (3) entity is to support organizations with similar missions. The organization clarifies it currently supports a foreign entity with a similar organizational name, yet state the domestic organization retains discretion and control of funds to ensure grants are properly used in furtherance of its mission. Although these statements are important, they need to be further supported by detailed documentation of organizational procedures of how the charity is exercising its control over funds, including total number of received applications, number of 
applicants qualified for receiving grant, number of distributed grants, purpose of distributed grants, and specific records on criteria used for determining grant recipients (PLR 201016089, 2010; Rev. Rule 59-95, 1959; Rev. Rule 75-65, 1975). A public charity should also develop detailed organizational bylaws clarifying the procedures involved in the cross-border giving process to further support the power and control of the domestic organization (Rev. Rule 66-79, 1966; Rev. Rule 75-65, 1975).

If a SFD entity (e.g., Sport 4 Society) decides to make cross-border grants, it is imperative the organization maintains detailed records since any legal cases involving concerns over limited administrative records are ruled against the applicant organization (New Dynamics Foundation v. United States, 2006; Rev. Rule 59-95, 1959). Similarly, tax courts have declined tax-exempt status under IRC §501(c)(3) for failure to maintain adequate records of financial transactions and organizational procedures (Western Catholic Church v. Commission, 1979). Moreover, denial of exemption has also been upheld against organizations for failing to provide detailed information on organizational activities for which tax-exemption status was claimed (Peoples Prize v. Commissioner, 2004).

An additional concern organizations engaged in cross-border grants must be prepared for involves provisions of the Patriot Act and U.S. Executive Order (E.O.) 13224. President George W. Bush issued E.O. shortly after the 9/11 terrorist attacks in 2001 to block provisions of property to and transactions with persons and entities who commit, threaten to commit, or support terrorism. Even donations of items intended to relieve human suffering such as food or clothing is included among the prohibited transactions (E.O. 13224, 2001). The USA Patriot Act (2002) was enacted shortly after E.O. 13224 and gives the executive branch broad powers to designate groups as terrorist organizations. Once so designated, the organization can have its property seized and assets frozen indefinitely pending the investigation. Most charitable organizations advance their goals in foreign countries through grant making, thus they must exercise reasonable care to ensure the grants are not diverted from their charitable purpose and that the provisions are not received by any organization on the Specially Designated Global Terrorist (SDGT) list. In addition, if an organization itself were targeted under E.O 13224 or the USA Patriot Act, its resources would be frozen. At least one U.S.-based charity, KindHearts for Charitable Humanitarian Development, was included on the Treasury Department's SDGT list and had its assets frozen. The charity was forced to cease its operations even though the SDGT listing was later reversed after the American Civil Liberties Union (ACLU) filed suit on behalf of the charity. KindHearts assets were finally released and it was able to transfer those assets to another charity to continue its humanitarian efforts, but the KindHearts organization was effectively shut down by the Treasury Department's listing (ACLU, 2012). To minimize the potential of such an outcome, a SFD organization such Sport 4 Society should carefully monitor the SDGT list on a periodic basis. Furthermore, this list should also be part of organizational procedures for evaluating prospective foreign grant recipients.

In light of the growing number of sport-related private foundations such as a professional athlete establishing his/her own charitable foundation, it also worth noting these types of organizations may also engage in cross-border giving 
for supporting SFD programs or organizations abroad as long as they follow either the equivalence determination process or the expenditure responsibility procedural process (Jenkins, 2007). The first process can be achieved by providing a written affidavit from a legal counsel in support of the equivalence of the foreign recipient organization to the requirements set forth in IRC §501(c)(3) (Rev. Proc. 92-94, 1992). The latter option requires the domestic foundation to provide detailed records of organizational procedures for ensuring reasonable use of cross-border grants including written agreements and on-going financial reports (IRC §4945(d)(4)). The organization in Revenue Ruling 75-65 (1975) was granted exemption and tax deductibility for conducting pre-grant inquiries on potential recipients, signing an agreement with chosen recipients, and monitoring the use of distributed funds to ensure its furthered its charitable mission. Overall, a private foundation interested in cross-border giving should exercise caution in its organizational design and procedures to ensure compliance with IRS regulations. Private foundations are also advised to embrace the preceding recommendations for public charities about maintaining detailed records of both organizational processes and outcomes.

\section{Conclusion}

Public charities and private foundations established in the U.S. can be valuable sources of financial support for international SFD programs and foreign nonprofit organizations. In order for organizations to be granted exemption for charitable purposes and tax deductibility for individual contributions, certain organizational structures and procedures need to be implemented. This paper has presented a brief overview of legal considerations for cross-border giving under U.S. laws and regulations. The extent to which a nonprofit exercises adequate discretion and control over financial grants for foreign programs is an integral aspect in determining issues concerning international giving.

The hypothetical SFD example (Sport 4 Society) presented in this paper highlights the implications of U.S. laws and regulations pertaining to cross-border giving and nonprofits engaged in international SFD efforts. It is essential for organizations such as Sport 4 Society to: (1) maintain clear and accurate governing documents, (2) develop detailed organizational bylaws and procedures providing effective oversight of how recipients are selected and funds are distributed, and (3) possess written agreements and financial controls that can be demonstrated and tracked to ensure transparency and accountability.

Overall, it is important to recognize the critical role of establishing adequate discretion and control of funds for any registered U.S. nonprofit engaged in cross-border support of foreign SFD efforts. Unfortunately, the IRS has yet to provide specific guidelines for what it considers 'adequate,' and it remains to be seen if such guidelines will be provided. In the meantime, however, the precedent legal cases and revenue rulings analyzed in this paper provides a guiding framework for foreign or domestic charitable organizations considering cross-border giving in support of international SFD efforts with funds from the U.S. 


\section{References}

Airlie Foundation v. I.R.S., 283 F. Supp. 2d 58 (D. D.C. 2003).

American Civil Liberties Union. (2012, May 1). Agreement removes KindHearts from list of groups with assets frozen, allows funds to go to humanitarian causes. ACLU.org. Retrieved from https://www.aclu.org/news/government-settles-charitys-lawsuit-over-unconstitutional-terrorism-probe

Berman, A. (2011). Isn't it ironic: The undermining of American public policy by American tax law, and the ramifications on middle east peace. Cardozo Public Law, Politics, \& Ethics Journal, 10, 81-129.

Better Business Bureau of Washington, D.C. v. United States, 326 U.S. 179 (1945).

Borchers, C. (2013). In nonprofit game, athletes post losing records. Boston Globe. Retrieved from http://www.bostonglobe.com/business/2013/02/24/nonprofit-game-many-athletes-post-losing-records/a0Eqoz6RUYORFhT0T0j0EO/story.html

BSW Group, Inc. v. Commissioner, 70 T.C. Memo 1978-352.

CCH Tax Law Editors. (2016). Tax research: Understanding sources of tax law. U.S. Master Tax Guide 2016. Riverwoods, IL: Wolters, Kluwer.

Charity Navigator. (2019). Giving statistics. Retrieved from https://www.charitynavigator.org/ index.cfm?bay $=$ content.view\& cpid $=42$

Church in Boston v. Commissioner, 71 T.C. Memo 1978-102.

Church of the Visible Intelligence that Governs the Universe v. United States, 4 Cl. Ct. 55 (1983).

Coakley, J. (2011). Youth sports: What counts as “positive development?" Journal of Sport \& Social Issues, 35, 306-324. https://doi.org/10.1177/0193723511417311

Coalter, F. (2013). 'There is loads of relationships here': Developing a programme theory for sportfor-change programmes. International Review for the Sociology of Sport, 48, 594-612. https:// doi.org/10.1177/1012690212446143

Commissioners for Special Purposes of Income Tax v. Pemsel, [1891] A.C. 531 (H.L. 1891).

Darnell, S. C., \& Dao, M. (2017). Considering sport for development and peace through the capabilities approach. Third World Thematics: A TWQ Journal, 2, 23-36. Retrieved from http:// www.tandfonline.com/doi/abs/10.1080/23802014.2017.1314772

Department of the Treasury. (2013). Letter 4038 (cg) (11-2005). Retrieved from http://www.irs.gov/ pub/irs-wd/1345031.pdf

Easter House v. United States, 12 Cl. Ct. 476 (1987), affirmed, 846 F.2d 78 (Fed. Cir. 1988).

Executive Order 13224. (2001, September 23). Federal Register, Vol. 66, No. 186, pp. 4907949083.

Fritz, J. (2016, December 26). How the IRS classified nonprofit organizations. The Balance. Retrieved from https://www.thebalance.com/how-the-irs-classifies-nonprofit-organiza$\underline{\text { tions-2501798 }}$

Giulianotti, R. (2012). The sport for development and peace sector: An analysis of its emergence, key institutions, and social possibilities. Brown Journal of World Affairs, 18, 279-293.

Giulianotti, R., Hognestad, H., \& Spaaij, R. (2016). Sport for development and peace: Power, politics, and patronage. Journal of Global Sport Management, 1, 129-141. https://doi.org/10.108 $\underline{0 / 24704067.2016 .1231926}$

GivingUSA. (2016). Giving USA 2016: The annual report on philanthropy for the year 2015. GivingUSA.org. Retrieved from https://givingusa.org/see-the-numbers-giving-usa-2016-infographic/

Global Impact. (2013). Assessment of U.S. giving to international causes. Charity.org. Retrieved 
from http://charity.org/sites/default/files/userfiles/pdfs/Assessment $\% 20$ of $\% 20$ US\%20Giving $\% 20$ to $\% 20$ International $\% 20$ Causes $\% 20$ FINAL.pdf

Green v. Kennedy, 309 F. Supp. 1127 (D. D.C. 1970).

GuideStar. (2017). Directory of charities and nonprofit organizations. Guidestar.org. Retrieved from https://www.guidestar.org/nonprofit-directory/public-societal-benefit.aspx

Harding Hospital v. United States, 505 F. 2d 1068 (6 ${ }^{\text {th }}$ Cir. 1974).

Hartmann, D., \& Kwauk, C. (2011). Sport and development: An overview, critique, and reconstruction. Journal of Sport \& Social Issues, 35, 284-305. https://doi. org $/ 10.1177 / 0193723511416986$

Hunter, G. (2016, April 7). Troy Aikman dissolving his foundation, moving \$1M into donor-advised fund at United Way. D Magazine. Retrieved from http://www.dmagazine.com/frontburner/2016/04/troy-aikman-dissolving-his-foundation-moving-1m-into-first-donor-advised-fundat-united-way/

Internal Revenue Service. (2017a). Exemption requirements - 501(c)(3) organizations. IRS.gov. Retrieved from https://www.irs.gov/charities-non-profits/charitable-organizations/exemption-requirements-section-501-c-3-organizations

Internal Revenue Service. (2017b). Life cycle of a private foundation - Starting out. IRS.gov. Retrieved from https://www.irs.gov/charities-non-profits/private-foundations/life-cycle-of-aprivate-foundation-starting-out

Jenkins, G. W. (2007, March). Soft power, strategic security, and international philanthropy. North Carolina Law Review, 85, 773-845.

Johnson, K. (2013). The charitable deductions game: Are the laws in your favor? Columbia Journal of Tax Law, 5, 69-99.

Kidd, B. (2008). A new social movement: Sport for development and peace. Sport in Society, 11, 370-380. https://doi.org/10.1080/17430430802019268

Lavigne, P. (2013). Athlete charities often lack standards. ESPN.com. Retrieved from http:// espn.go.com/espn/otl/story//id/9109024/top-athletes-charities-often-measure-charity-experts-say-efficient-effective-use-money

McGlotten v. Connally, 338 F. Supp. 448 (D. D.C. 1972).

National Center for Charitable Statistics. (2013). Quick facts about nonprofits. NCCS.org. Retrieved from http://nccs.urban.org/data-statistics/quick-facts-about-nonprofits

New Dynamics Foundation v. United States, 70 Fed. Cl. 782, 2006 U.S. Claims LEXIS 103 (2006).

Paine, R. (2004). The tax treatment of international philanthropy and public policy. Akron Tax Journal, 19, 1-24.

Peebles, J. (2017). Cross-border grant making by private foundations. CAF America. Retrieved from http://www.cafamerica.org/cross-boarder-grant-making-by-private-foundations/

Peoples Prize v. Commissioner, Tax Court Memorandum 2004-12.

Pozen, D. (2006, December). Remapping the charitable deduction. Connecticut Law Review, 39, 531-599.

IRC $\S 170(a)$.

IRC $\S 170(c)(2)$.

IRC $\S 501(\mathrm{c})(3)$.

IRC $\S 502(\mathrm{c})(4)$.

IRC $\S 509$ (a).

I.R.S. Priv. Ltr. Rul. 200931059 (July 31, 2009). 
I.R.S. Priv. Ltr. Rul. 201016089 (April 23, 2010).

Rev. Proc. 92-94, 1992-1 C.B. 507.

Rev. Rule 56-304, 1956-2 C.B. 306.

Rev. Rule 59-95, 1959-1 C.B. 627.

Rev. Rule 63-252, 1963-2 C.B. 101.

Rev. Rule 65-298, 1965-2 C.B. 163.

Rev. Rule 66-79, 1966-1 C.B. 48.

Rev. Rule 68-117, 1968-1 C.B. 251.

Rev. Rule 68-489, 1968-2 C.B. 210.

Rev. Rule 71-460, 1971-2 C.B. 231.

Rev. Rule 73-440, 1973-2 C.B. 177.

Rev. Rule 74-16, 1974-1 C.B. 126.

Rev. Rule 75-65, 1975-1 C.B. 79.

Schulenkorf, N. (2012). Sustainable community development through sport and events: A conceptual framework for sport-for-development projects. Sport Management Review, 15(1), 1-12.

Schulenkorf, N. (2017). Managing sport-for-development: Reflections and outlook. Sport Management Review, 20, 243-251. http://dx.doi.org/10.1016/j.smr.2016.11.003

Svensson, P. G., \& Levine, J. (2017). Rethinking sport for development and peace: The capability approach. Sport in Society, 20, 905-923. https://doi.org/10.1080/17430437.2016.1269083

United States v. Wells Fargo Bank, 485 U.S. 351, 108 S.Ct. 1179, 99 L.Ed. 2 d 368 (1900).

Uniting and Strengthening America by Providing Appropriate Tools Required to Intercept and Obstruct Terrorism (USA Patriot Act) of 2001, Pub. L. 107-56, 115 Stat.276 (Oct. 26, 2001).

U.S. Department of the Treasury. (2017). Resource Center: Specially designated nationals and blocked persons list (SDN) human readable lists. Treasury.gov. Retrieved from https://www. treasury.gov/resource-center/sanctions/SDN-List/Pages/default.aspx

U.S. Department of the Treasury. (2006). Anti-Terrorism financing guide for voluntary best practices for U.S.-based charities. Treasury.gov. Retrieved from https://www.treasury.gov/ resource-center/terrorist-illicit-finance/Documents/guidelines charities.pdf

Walsh, D. (2012, September 11). Public charity or private foundation - Why does it matter? Planned Giving Design Center. Retrieved from http://www.pgdc.com/pgdc/public-charity-orprivate-foundation-why-does-it-matter

Williams, D. (2016). Taking a knee: An analysis of the decision to relinquish its $\S 501(\mathrm{c})(6)$ federal tax exemption. Journal of Legal Aspects of Sport, 26, 127-143. https://doi.org/10.1123/jlas.2015$\underline{0008}$

Williams, D., \& Seifried, C. (2013a). The taxing postseason: The potential impact of unrelated business income taxation on college football bowl organizers. Journal of Legal Aspects of Sport, 23, 72-90. https://doi.org/10.1123/jlas.23.2.72

Williams, D., \& Seifried, C. (2013b). Analyzing the prospects of the unrelated business income tax and $\S 501(\mathrm{c})(3)$ on Division I athletic activities. The Journal of Sport, 2, 22-60.

Western Catholic Church v. Commissioner, 73 T.C. 196, 206 (1979). 